\title{
A Two-Component System Plays an Important Role in the Root-Colonizing Ability of Pseudomonas fluorescens Strain WCS365
}

\author{
Linda C. Dekkers, Cees Jan P. Bloemendaal, Letty A. de Weger, Carel A. Wijffelman, \\ Herman P. Spaink, and Ben J. J. Lugtenberg \\ Leiden University, Institute of Molecular Plant Sciences, Clusius Laboratory, Wassenaarseweg 64, 2333AL \\ Leiden, The Netherlands \\ Accepted 7 October 1997.
}

We describe the characterization of a novel Tn5lacZ colonization mutant of the efficiently colonizing Pseudomonas fluorescens strain WCS365, mutant strain PCL1210, which is at least 300- to 1,000-fold impaired in colonization of the potato root tip after co-inoculation of potato stem cuttings with a 1:1 mixture of mutant and parental cells. Similarly, the mutant is also impaired in colonization of tomato, wheat, and radish, indicating that the gene involved plays a role in the ability of $P$. fluorescens WCS365 to colonize a wide range of plant species. A 3.1-kb DNA fragment was found to be able to complement the observed mutation. The nucleotide sequence of the region around the Tn5lacZ insertion showed three open reading frames (ORFs). The transcriptional start site was determined. The operon is preceded by an integration host factor (IHF) binding site consensus sequence whereas no clear -10 and -35 sequences are present. The deduced amino acid sequences of the first two genes of the operon, designated as colR and cols, show strong similarity with known members of two-component regulatory systems. ColR has homology with the response regulators of the OmpR-PhoB subclass whereas ColS, the product of the gene in which the mutation resides, shows similarity to the sensor kinase members of these two-component systems. Hydrophobicity plots show that this hypothetical sensor kinase has two transmembrane domains, as is also known for other sensor kinases. The product of the third ORF, Orf222, shows no homology with known proteins. Only part of the orf222 gene is present in the colonizationcomplementing, 3.1-kb region, and it therefore does not play a role in complementation. No experimental evidence for a role of the ColR/ ColS two-component system in the suspected colonization traits chemotaxis and transport of exudate compounds could be obtained. The function of this novel two-component system therefore remains to be elucidated. We conclude that colonization is an active process in which an environmental stimulus,

Corresponding author: Linda C. Dekkers; Telephone: (+31) 71-527 5065, Fax: (+31) 71-527 5088; E-mail: Dekkers@ rulbim.leidenuniv.nl

Nucleotide and/or amino acid sequence data have been submitted to the DDBJ/EMBL/GenBank data base under accession number Y09798. through this two-component system, activates a so far unknown trait that is crucial for colonization.

Infections by microbial pathogens are very common in plants and are responsible for the loss of approximately one third of the crop yield (Lugtenberg et al. 1994). Many plant diseases are treated with chemical fungicides. However, several of these chemicals become a threat to health and to the environment when they contaminate drinking water. Therefore, most governments have introduced a policy of banning several of the available chemical pesticides. This policy has increased the interest in microbiological control of plant diseases by the use of plant growth promoting rhizobacteria (PGPRs) (Schroth and Hancock 1982; Schippers et al. 1987; Lugtenberg et al. 1991). One group of PGPRs that receives considerable attention is that of the fluorescent Pseudomonas spp. The mechanisms of action of these pseudomonads have recently been extensively reviewed (Thomashow and Weller 1996). PGPRs usually attack pathogens by the production of antifungal factors (AFFs). In order to effectively protect the plant root, these AFFs must be present on the whole root system, especially on the younger parts that are most susceptible to infections. Therefore, the delivery system of these AFFs, i.e., rhizosphere colonization, is an important biocontrol trait in PGPR strains. Colonization often appears to be even the limiting factor for biocontrol (Schippers et al. 1987; Weller 1988).

We initiated a program to identify the major bacterial traits involved in colonization. Initially, we have isolated mutants in traits that, we suspected, play a major role in colonization. By comparison of the colonization behavior of wild-type and mutant strains we have shown that the ability of Pseudomonas to produce flagella (de Weger et al. 1987b), synthesize the Oantigen of lipopolysaccharides (LPS) (de Weger et al. 1989), and synthesize amino acids (Simons et al. 1997) is crucial for colonization. Moreover, auxotrophy for vitamin B1 and a slightly increased generation time were also correlated with poor colonization ability (Simons et al. 1996). However, this approach of studying suspected traits is limited by our knowledge of bacterial physiology. Therefore, we have now started with the more objective approach to randomly mutagenize the effectively colonizing strain $P$. fluorescens WCS365, which is one of the most efficient root colonizers of potato (Geels and 
Schippers 1983a; Brand et al. 1990; Glandorf 1992; Simons et al. 1996). The resulting individual mutant cells were screened in competition with those of the parental strain for their ability to colonize the root tip after inoculation of sterile potato stem cuttings or germinated seeds. Following isolation and characterization of the corresponding wild-type genes, this approach can lead to the identification of novel colonization signals and traits.

\section{RESULTS}

\section{Preliminary characterization of the colonization-defective mutant PCL1210.}

Mutant strain PCL1210 was originally isolated as a putative colonization mutant by screening on potato plantlets in the compact system as described in Materials and Methods (Lugtenberg and de Weger 1992; Brand et al. 1990; Glandorf 1992). We therefore tested mutant strain PCL1210 for the known colonization traits of motility, presence of $\mathrm{O}$-antigen of LPS, ability to produce amino acids and vitamin B1, and high growth rate in rich liquid medium in competition with the parental strain (results not shown). In addition, cell envelope protein patterns of the two strains were compared in order to test whether PCL1210 is indeed a derivative of strain P. fluorescens WCS365. In all these tests the behavior of mutant PCL1210 was indistinguishable from that of the parental strain (data not shown).

Subsequently, mutant strain PCL1210 was retested twice for its ability to colonize the root tip after inoculation of potato stem cuttings with a 1:1 mixture of cells of mutant PCL1210 and its parental strain P. fluorescens WCS365. The results (Table 1) show that the mutant strain PCL1210 is statistically significantly and at least 300- to 1,000-fold impaired in its ability to colonize the root tip in competition with its parent. The mutant also colonizes the higher parts of the root system, close to the green parts of the plant, 100-fold less efficiently than the parent in competition experiments with the parental strain (results not shown).

When potato stem cuttings were inoculated with cells of mutant PCL1210 alone, the cells colonized the root tip as effectively as the parental strain (results not shown). This result was confirmed by scanning electron microscopy, which also

Table 1. Root tip colonization of mutant strain PCL1210 after 1:1 coinoculation with the wild-type strain Pseudomonas fluorescens WCS365 in gnotobiotic assays ${ }^{\mathrm{z}}$

\begin{tabular}{lcc}
\hline & \multicolumn{1}{c}{$\begin{array}{c}\text { Root tip colonization } \\
{\left[\log _{\mathbf{1 0}}(\mathbf{C F U}+\mathbf{1} / \mathbf{c m}) \text { root tip }\right]}\end{array}$} \\
\cline { 2 - 3 } Colonization conditions & WCS365 & PCL1210 \\
\hline $\begin{array}{l}\text { Compact sand column } \\
\text { Potato (experiment 1) }\end{array}$ & $5.4 \mathrm{a}$ & $0.2 \mathrm{~b}$ \\
Potato (experiment 2) & $5.4 \mathrm{a}$ & $1.1 \mathrm{~b}$ \\
Standard sand column & \\
$\quad$ Potato & $4.5 \mathrm{a}$ & $0.2 \mathrm{~b}$ \\
Tomato & $4.1 \mathrm{a}$ & $0.7 \mathrm{~b}$ \\
Wheat & $4.5 \mathrm{a}$ & $2.5 \mathrm{~b}$ \\
Radish & $3.9 \mathrm{a}$ & $1.4 \mathrm{~b}$ \\
\hline $\mathrm{z}$ In every experiment 10 plants were inoculated and individually proc- \\
essed. Experiments were performed at least two times. When values in \\
the same row are followed by a different letter, they are significantly \\
different at $P=0.05$ on nonparametric multiple comparisons by Wil- \\
coxon-Mann-Whitney (Sokal and Rohlf 1981). Detection limit is 2.4 \\
log CFU/ml.
\end{tabular}

showed that the mutant was, like the wild type, able to form micro-colonies (results not shown).

To test the colonization behavior of mutant PCL1210 on different plants, germinated seeds of radish, tomato, and wheat as well as sterile potato stem cuttings were inoculated with a 1:1 mixture of mutant and wild type and root tip colonization was determined in the standard sand column. The results (Table 1) show that on all tested plant species the mutant is strongly impaired in colonization.

\section{Isolation of the wild-type colonization locus.}

Total DNA of mutant PCL1210 was digested with the restriction enzyme SalI, which divides the Tn5lacZ (Lam et al. 1990) present in mutant PCL1210 into two fragments. One of these fragments contains an intact kanamycin resistance gene that, after ligation of the total DNA of mutant PCL1210 into pIC20H (Marsh et al. 1984), allows selection for the presence of kanamycin resistance encoding plasmids. The resulting plasmid, pMP5203, harbors a large part of Tn5lacZ but also a $1.5-\mathrm{kb}$ flanking region containing part of the gene that is mutated by the Tn5lacZ insertion (Fig. 1). The 1.5-kb flanking fragment was used in further experiments. An EcoRI-EcoRI fragment (see Figures 1 and 2) of pMP5203 was cloned into pME3049 (Voisard et al. 1994), which behaves as a suicide plasmid in Pseudomonas. The resulting plasmid, pMP5204, was transferred by triparental mating to the wild-type strain $P$. fluorescens WCS365. A single homologous recombination event led to insertion of pMP5204 into the chromosomal DNA, and yielded a kanamycin (pME3049) resistant $P$. fluorescens WCS365 strain. The chromosomal DNA of this strain was isolated and a restriction enzyme digestion with BamHI was performed followed by ligation and transformation of the digestion mixture. After selection for kanamycin resistance,

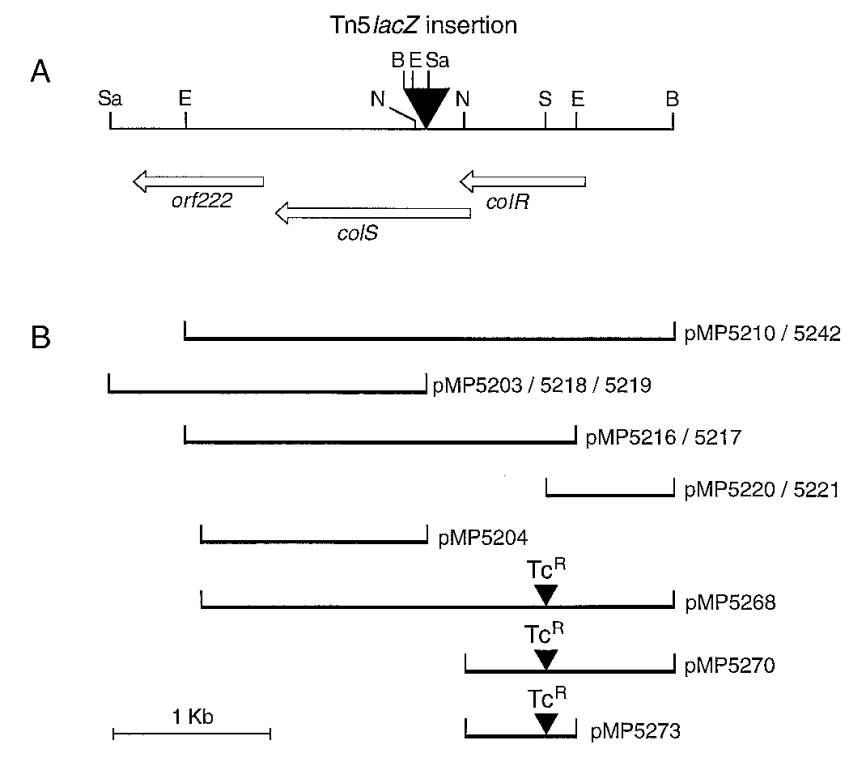

Fig. 1. Restriction map of the larger DNA fragment isolated from Pseudomonas fluorescens with the help of pME3049 (pMP5210). A, Open arrows indicate direction and size of the three open reading frames that were found. Location of the Tn5lacZ insertion in the genome of PCL1210 is indicated. B, Fragments that were used for complementation (pMP5242) or single-strand-DNA sequencing are shown. B, BamHI; E, EcoRI; N, NcoI; S, SmaI; Sa, SalI. 


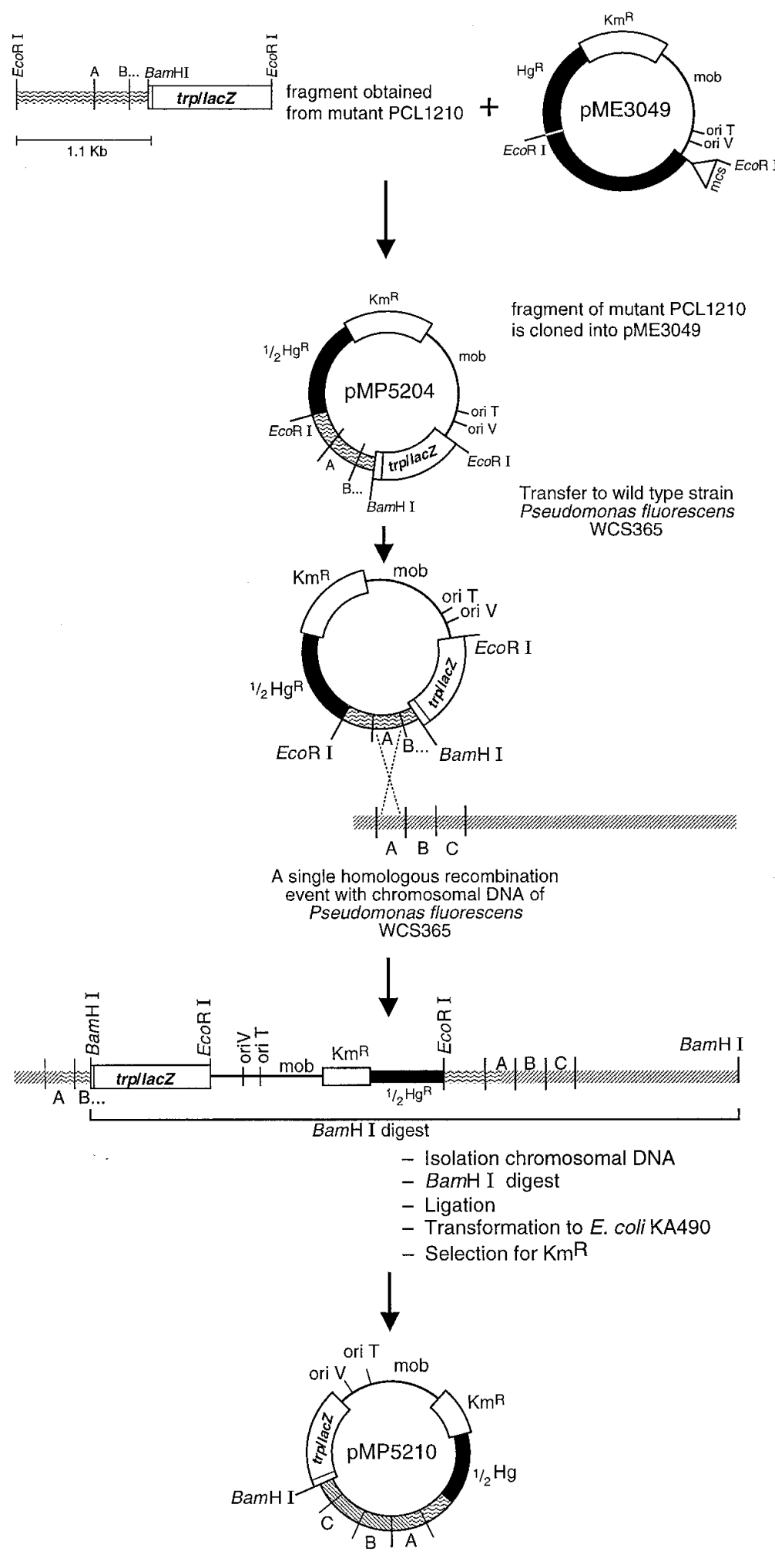

Fig. 2. Isolation of a larger DNA fragment of PCL1210 with the help of plasmid pME3049 (Voisard et al. 1994). An EcoRI-EcoRI fragment containing a part of Tn5lacZ and a part of the gene mutated in PCL1210 was ligated into pME3049. The resulting construct, pMP5204, was brought back to the wildtype $P$. fluorescens strain WCS365 by triparental mating, followed by selection for a single homologous recombination event. The chromosomal DNA containing the pME3049 plasmid was subsequently digested with BamHI, ligated, and transformed into Escherichia coli. The resulting plasmid pMP5210 contains a fragment of mutant PCL1210 spanning the Tn5lacZ insertion, which is theoretically approximately in the middle (Voisard et al. 1994; Schnider et al. 1995 ). 
pMP5210 was isolated and appeared to contain a 3.1-kb DNA fragment of the wild-type strain. (Figs. 1 and 2).

The 3.1-kb fragment was cloned into pWTT2081, a plasmid that is stable in the rhizosphere (van der Bij et al. 1996). The resulting plasmid, pMP5242, appeared to complement the mutant's colonization defect in competition with the parental strain (see Table 2).

\section{Generation of a new colonization mutant with homologous recombination.}

These experiments were performed to verify that the mutation as observed in mutant PCL1210 is due to the Tn5lacZ insertion and not to a mutation elsewhere. Plasmid pMP5273 (see Fig. 1), which contains a part of the colS gene as well as a part of the colR gene, and a tetracycline resistance gene, was introduced into the wild-type P. fluorescens WCS365. After selection for single or double homologous recombination, the newly generated mutant, PCL1251, was tested for its competitive colonization abilities (see Table 2). Competitive colonization experiments showed that PCL1251, like PCL1210, is statistically significantly impaired in its colonization ability, compared with the parental strain WCS365.

\section{Nucleotide sequence analysis.}

The SalI-SalI DNA fragment of PCL1210, present in pMP5203, was also used for sequence analysis (Sanger et al. 1977) to determine the exact position of the Tn5lacZ insertion in the DNA fragment. This showed that the isolated 3.1$\mathrm{kb}$ DNA fragment present in pMP5210 was identical to the Tn5lacZ flanking fragment in pMP5203. A number of overlapping DNA fragments of the complementing region (see Figure 1) were cloned into M13mp19, and 3,347 bp were sequenced. Computer analysis with the CODON PREFERENCE program, which is part of the University of Wisconsin GCG software, was used to identify possible proteinencoding regions. This analysis revealed three potential open reading frames (ORFs) designated as colR, cols, and orf222, respectively (Fig. 1). Both colR and cols are preceded by a Shine-Dalgarno sequence, 5 bp AGAGG for colR and $6 \mathrm{bp}$ GGAGG for cols. The third ORF contains a ShineDalgarno sequence (GGAGG) located 9 bp upstream of the translational start site.

Table 2. Potato root tip colonization of the complemented mutant PCL1210 and a newly generated colonization mutant of Pseudomonas fluorescens WCS365 after 1:1 co-inoculation with the wild-type strain in gnotobiotic assays ${ }^{\mathrm{Z}}$

\begin{tabular}{|c|c|c|}
\hline \multirow[b]{2}{*}{ Strains tested } & \multicolumn{2}{|c|}{$\begin{array}{l}\text { Root tip colonization }\left[\log _{10}\right. \\
(\mathrm{CFU}+1 / \mathrm{cm}) \text { root tip] }\end{array}$} \\
\hline & WCS365 & PCL1210 \\
\hline $\begin{array}{l}\text { WCS365 vs PCL1210 (parent vs original } \\
\text { colonization mutant }\end{array}$ & $5.9 \mathrm{a}$ & $3.5 \mathrm{~b}$ \\
\hline $\begin{array}{l}\text { PCL1240 vs PCL1242 (parent vs co m- } \\
\text { plemented mutant) }\end{array}$ & $5.4 \mathrm{a}$ & $4.6 \mathrm{a}$ \\
\hline $\begin{array}{l}\text { PCL1500 vs PCL1251 (parent vs the } \\
\text { newly generated colonization mutant) }\end{array}$ & $5.6 \mathrm{a}$ & $2.9 \mathrm{~b}$ \\
\hline \multicolumn{3}{|c|}{$\begin{array}{l}{ }^{\mathrm{z}} \text { In every experiment } 10 \text { plants were inoculated and individually proc- } \\
\text { essed. Experiments were performed at least two times. When values in } \\
\text { the same row are followed by a different letter, they are significantly } \\
\text { different at } P=0.05 \text { on nonparametric multiple comparisons by Wil- } \\
\text { coxon-Mann-Whitney (Sokal and Rohlf 1981). Detection limit is } 2.4 \\
\log \text { CFU/ml. }\end{array}$} \\
\hline
\end{tabular}

The putative transcription start sites on the $5^{\prime}$ end of colR were determined, and neither -10 nor -35 consensus sequences are clearly present. However, a very good putative integration host factor (IHF) binding site (Goosen and van de Putte 1995) is present, which overlaps the putative -35 sequence when the second transcription start site is considered as the actual start site. Binding studies with purified Escherichia coli IHF showed, however, that the purified IHF is not binding to the IHF binding site.

The first ORF, colR, is predicted to encode protein containing 227 amino acids with a molecular mass of $25.387 \mathrm{kDa}$. The second ORF, colS, in which the Tn5lacZ is inserted, can encode a protein of 435 amino acids with a predicted molecular mass of $47.564 \mathrm{kDa}$. The third ORF, orf222, could encode a protein of 222 amino acids with a predicted molecular mass of $25.807 \mathrm{kDa}$.

\section{Comparison of the deduced amino acid sequences} of the three ORFs with known protein sequences.

The amino acid sequence deduced from the first ORF, ColR, shows highest similarity with RcaC (Chiang et al. 1992) (identity 40\%, similarity 59\%) and PmrA (Roland et al. 1993) (identity $39 \%$, similarity 60\%), two regulatory proteins known as response regulators (Fig. 3). ColS shows homology with histidine kinase proteins such as BasS (Nagasawa et al. 1993) (identity 30.5\%, similarity 50\%) and PmrB (Roland et al. 1993) (identity 29\%, similarity 52\%) (Fig. 4). Although the codon usage bias of the last part of the DNA sequence of orf222 (results not shown) is not typical for Pseudomonas, we cannot exclude that orf 222 encodes a protein. However, the 222 -amino-acid sequence deduced from $\operatorname{orf} 222$ shows no homology with known proteins.

With the prediction method of Kyte and Doolittle (1982), which is part of the University of Wisconsin GCG software, a hydrophobicity plot was drawn of the deduced amino acid sequence of ColS. This result predicts two hydrophobic regions at the N-terminal part of the protein (Fig. 4D).

\section{Homology with ColR/ColS in other strains.}

In order to test whether other Pseudomonas strains have any homology with the colR and cols genes, the chromosomal DNA of Pseudomonas spp. WCS134, WCS379, P. fluorescens WCS315, P. putida strains WCS085 (Geels and Schippers 1983a; de Weger et al. 1986) and RC1 (Bolton et al. 1989), $P$. fluorescens strains WCS307 and WCS374, and $P$. putida strain WCS358 (Geels and Schippers 1983b) was isolated. No clear hybridization with the chromosomal DNA of the tested strains was observed when an NcoI-EcoRI DNA fragment (Fig. 1) containing the response regulator, or an EcoRI-NcoI DNA fragment (Fig. 1) containing part of the sensor kinase and part of orf 222 was used as a radioactive probe (results not shown).

\section{Is mutant PCL1210 impaired in chemotaxis toward, or in uptake of, major exudate nutrients?}

The observation that colonization mutant PCL1210 is impaired in the functioning of a two-component system prompted us to reinvestigate the possibility that the mutation affects one of the already known colonization traits in which two-component systems are known to play a role. Chemotaxis could play a role as part of the established colonization trait motility. Similarly, transport of exudate carbon sources could 
play a role in the suspected colonization trait high growth rate. Chemotaxis is regulated by the CheY/A two-component regulatory system (Swanson et al. 1994) and the transport of di- and tri-carboxylic acids is also regulated by two-component systems (Stock et al. 1989, 1990). The chemotactic abilities of P. fluorescens WCS365 and of mutant PCL1210 were compared on swarm plates containing the identified tomato root exudate compounds malic acid, fumaric acid, citric acid, succinic acid, glucose, ribose, galactose, and fructose (M. Simons, personal communication). However, no difference was observed between the chemotactic abilities of the wild type and the mutant (results not shown).

Since impaired transport will result in impaired growth, and since measurement of growth on many substrates is technically much more feasible than measurement of transport, we measured growth rates at high and low substrate concentrations. Generation times of wild-type strain $P$. fluorescens WCS365 and mutant PCL1210, as judged from measurements of $\mathrm{OD}_{620}$ values of cells grown in liquid medium containing $0.2 \%$ of the carbon sources mentioned above, were indistinguishable. Growth in competition in BM containing tomato root exudate as the carbon source showed no differences between the parental and the mutant strain. These results indicate that impaired transport of the major exudate carbon sources is not the reason for the mutant's poor colonization ability.

Finally, the Biolog system, which indicates the ability of a bacterial strain to oxidize 95 different carbon sources (Bochner 1989), was used to test whether P. fluorescens WCS365 and mutant PCL1210 differ in their behavior toward these carbon sources. The results (not shown) did not indicate any differences between the two strains.

\section{DISCUSSION}

\section{Characterization of mutant PCL1210} as a novel colonization mutant.

Colonization often is the limiting step in biocontrol of plant diseases caused by pathogenic fungi (Schippers et al. 1987; Weller 1988). In this paper we describe the analysis of mutant PCL1210, a derivative of the efficient root colonizer $P$. fluorescens WCS365, which is impaired in its ability to colonize

$\begin{array}{ll}\text { A } & \text { DD-box } \\ \text { ColR } \\ \text { BasR } \\ \text { Pmrasal } \\ \text { TctDsal } \\ \text { CopRpseu } \\ \text { CutR } \\ \text { RcaC } \\ \\ \\ \\ \text { K-box } \\ \text { ColR } \\ \text { BasR } \\ \text { PmrAsal } \\ \text { TctDsal } \\ \text { CopR } \\ \text { CutR } \\ \text { RcaC }\end{array}$

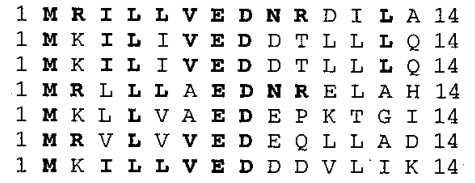

D-box
ColR
BasR
PmrAsal
TCtDsal
CopR
CutR
RcaC

46 D L I V I D I M L P G I D G Y T L C K R L 66 46 S L V V V L 46 S L $\quad$ M V V L 46 A L A V L D I N M P G M D G L E V V O R L 66 46 D I L I I D D V M M P G L D G W E V I R R L 66 $46 \mathrm{D} \mathrm{V} \mathrm{V} \mathrm{V} \mathrm{I} \mathrm{D} \mathrm{R} \mathrm{D} \mathrm{L} \mathrm{P} \mathrm{L} \mathrm{V} \mathrm{H} \mathrm{G} \mathrm{D} \mathrm{D} \mathrm{V} \mathrm{C} \mathrm{R} \mathrm{K} \mathrm{I} 56$

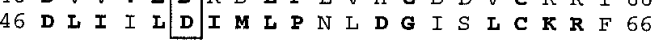

\begin{tabular}{|l|l|c|}
\hline & Percentage similarity with ColR & Percentage identity with ColR \\
\hline BasR & 59 & 38 \\
PmrAsal & 60 & 39 \\
TctDsal & 58 & 39 \\
CopR & 61 & 38.5 \\
CutR & 60 & 37.5 \\
RcaC & 59 & 40 \\
\hline
\end{tabular}

C

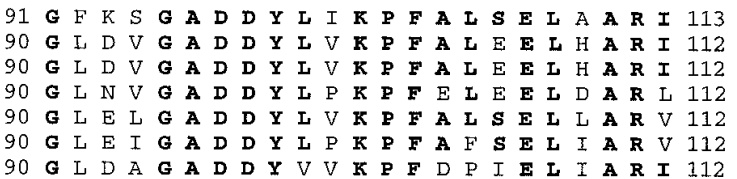

B

DNA binding domain

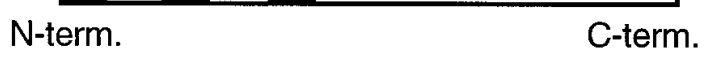

Fig. 3. Amino acid sequence similarity in the three conserved regions (Stock et al. 1989; Albright et al. 1989) of the response regulator ColR. A, Sequences of the response regulator ColR, BaeS (Nagasawa et al. 1993), and CpxA (Rainwater and Silverman 1990; Plunkett et al. 1993) from Escherichia coli, PmrAsal (Roland et al. 1993) and TctDsal (Widenhorn et al. 1989) from Salmonella typhimurium, and CopR from Pseudomonas syringae (Mills et al. 1993). CutR was isolated from Streptomyces lividans (Tseng and Chen 1991) and RcaC from the cyanobacterium Fremyella diplosiphon (Chiang et al. 1992). Conserved aspartic acid residue that is phosphorylated by a sensor kinase is boxed. All identical residues are shown in bold. B, Overall similarity and identity between ColR and the other regulatory proteins. C, An overview of the homologous domains within the regulator protein. 
roots of various plants. Mutant PCL1210 appeared to be indistinguishable from the parental strain with respect to the known colonization traits of motility (de Weger et al. 1987b), production of the O-antigen of LPS (de Weger et al. 1989), amino acids (Simons et al. 1997), and vitamin B1, and high growth rate (Simons et al. 1996). Competitive growth in SSM in competition with the wild type showed that the mutant is as fit as the wild type under the tested conditions. Therefore, mutant PCL1210 must be impaired in a novel colonization trait.

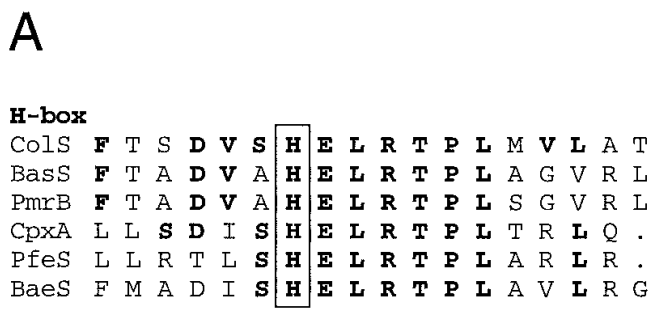

DF-box

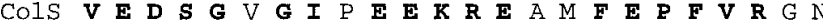

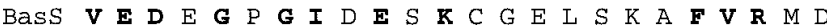
PmrB V E D E G P G I D E $S$ K C G K L S $\mathbf{E} A$ A $\mathbf{V}$ R $M$

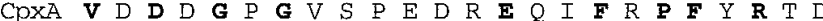

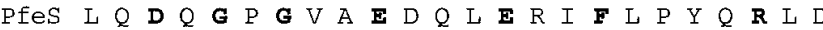

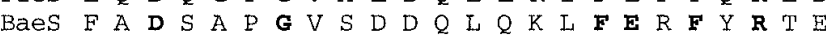

\section{N-box}

Cols $T$ L $Y$ N $\mathbf{N}$ A

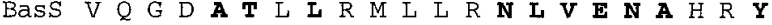

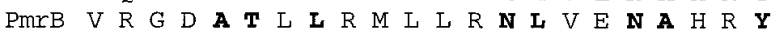

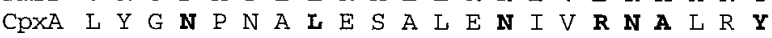
Pfes $V$ E $V$ H L D S I A Q A M E N L I R N A I R H Baes V F G D R D R I M $Q$ L $F$ N N I I $E$ E N $S$ L $R$ Y

\section{G-box}

ColS G L G I G I $S I V O R$ I $\mathbf{S}$. N $\mathbf{Q}$ G W $T$

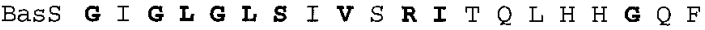
PmrB G I G I G I S I V S R I T $Q$ L H Q G $Q F$ $\operatorname{CpxA} \mathbf{G} T$ G I G I A I V E T A I Q $Q H R$ G W. Pfes G F G L G I A I A R R A I E L Q G G R. Baes G $S$ G I G I A I C L N I V $\mathbf{E} A H$ N $\mathbf{G} R$.

B

\begin{tabular}{|ll|c|}
\hline \multicolumn{2}{|r|}{ Percentage similarity with Cols } & Percentage identity with ColS \\
\hline Bass & 52 & 30.5 \\
PmrB & 52 & 29 \\
CpxA & 53 & 26 \\
PfeS & 54 & 28 \\
Baes & 48 & 24.5 \\
\hline
\end{tabular}

C

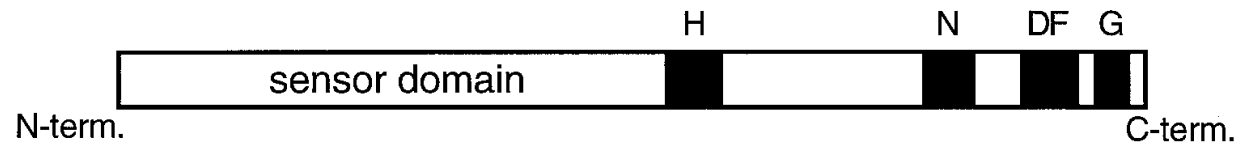

D

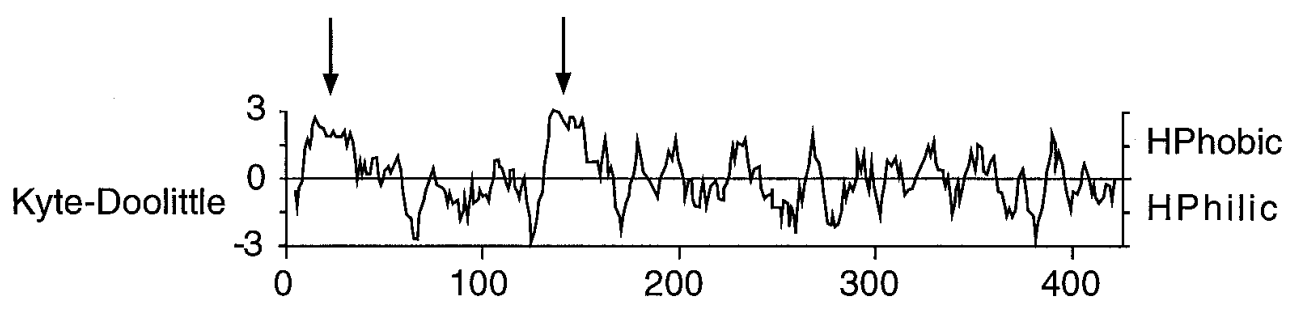

Fig. 4. Amino acid sequence similarity of the sensor kinase ColS. A, Similarity of four conserved regions (Stock et al. 1989; Albright et al. 1989) of the ColS sensor kinase protein with those of the sensor kinases BasS and BaeS, both described by Nagasawa et al. (1993), CpxA (Rainwater and Silverman 1990; Plunkett et al. 1993) from Escherichia coli, PmrB from S. typhimurium LT2 (Roland et al. 1993), and PfeS from Pseudomonas aeruginosa (Dean and Poole 1993). Site of autophosphorylation, the conserved histidine residue, is boxed. All identical residues are shown in bold. B, Overall similarity and identity between ColS and the other sensor kinases. C, Overview of the homologous domains within the sensor kinase protein. D, Hydrophobicity plot of the sensor kinase ColS. A hydrophobicity plot of the deduced amino acid sequence of ColS was drawn with a Kyte and Doolittle (1982) prediction model that is part of the PEPLOT program of GCG Wisconsin. Hydrophobic regions of more than 20 amino acids are marked by arrows. 


\section{Analysis of colonization behavior.}

Mutant PCL1210 was initially isolated as a mutant impaired in colonization of the potato root. Using two slightly different colonization assays, we showed that mutant PCL1210, in competition with the wild-type strain P. fluorescens WCS365, is strongly impaired in colonization of the potato root tip (Table 1). Under these conditions competitive colonization of the upper parts of the potato root system appeared to be reduced (results not shown). When mutant PCL1210 is applied alone on the potato root its colonization behavior is indistinguishable from that of the wild type, indicating that the mutant is impaired in competitive colonization rather than in colonization per se. Furthermore, these results show that colonization is not reduced because of sensitivity of the mutant toward toxins exuded by the root. Previously described data of Glandorf (1992) have shown that the colonization of mutant PCL1210, then known as mutant 10, on potato is also impaired in field soil, especially on the lower parts of the root systems (4 to $6 \mathrm{~cm}$, total length $6 \mathrm{~cm}$ ), indicating that the impaired colonization trait also plays a role under agricultural conditions. The impaired colonization gene of mutant PCL1210 not only plays a role in the colonization of potato roots but also in the colonization of tomato, radish, and wheat roots (Table 1), indicating that the novel colonization trait plays a major role in colonization of a wide range of plant species.

The newly generated mutant PCL1251 was also tested for its colonization abilities and showed a statistically significant decreased colonization ability (see Table 2), indicating that the mutation in mutant PCL1210 is caused by a defect in colS and not by a mutation elsewhere.

\section{Regulation of colR/cols.}

Considering the lack of a promoter sequence upstream of $\operatorname{col} S$, and the fact that the termination codon of colR overlaps with the ORF of $\operatorname{col} S$, it is likely that both genes constitute one operon. The third ORF, orf222, which is situated $120 \mathrm{bp}$ farther downstream of the $\mathrm{colR} / \mathrm{col} S$ operon, is not preceded by any putative promoter sequences. Therefore, it is likely that this third ORF, together with colR and cols, constitutes one operon. Complementation with the 3.1-kb fragment, in which a substantial part of $\operatorname{orf} 222$ is missing, showed that $\operatorname{orf} 222$ is not required for complementation of mutant PCL1210. The fact that the presumed colR/cols, orf 222 operon is not preceded by a clear $\sigma^{70}$ consensus sequence suggests that expression of this operon requires the use of an alternative $\sigma$ factor or the use of an additional transcription factor. The third transcription start site, which is located 222 bp upstream of the translation start site, could be a likely candidate to bind such an additional transcriptional activator. Another likely candidate to enhance transcription is the almost perfect IHF-binding site (Goosen and van der Putte 1995) located directly upstream of the transcriptional start site, overlapping the putative -35 sequence. The lack of interaction with purified $E$. coli IHF protein in binding studies may be due to the lack of one or more other factors required for formation of such a complex, or to a difference between E. coli and Pseudomonas IHF.

\section{Possible function of ColR/ColS.}

The deduced amino acid sequences of the first two ORFs (ColR and ColS) share considerable similarity with a number of proteins that are members of two-component regulatory systems. Two-component systems are able to respond to a large variety of environmental stimuli, such as changes in osmolarity (Comeau et al. 1985) and phosphate concentration (Makino et al. 1986). By autophosphorylation of a conserved histidine residue, the sensor kinase member of the twocomponent system is able to phosphorylate the response regulator, which in turn is able to activate a gene or a set of genes (Albright et al. 1989; Stock et al. 1989, 1990; Charles et al. 1992).

ColR, the first gene of the operon, shows homology with various response regulators that are members of these twocomponent systems. It has been shown (Albright et al. 1989; Stock et al. 1995) that these response regulators are highly conserved in the N-terminal region of the protein (see Figure 3). This N-terminal region contains three conserved boxes (see Figure 3). The second one contains the conserved aspartic acid residue (D51), which is phosphorylated by the second member of the two-component system, the histidine kinase protein. The C-terminal domain of ColR is shared by OmpR (Comeau et al. 1985) and PhoB (Makino et al. 1986). This subclass of response regulators shares C-terminal homology with the N-terminal region of the ToxR protein, a transcriptional activator that regulates cholera toxin production (Miller et al. 1987). These shared C-terminal domains between the different subclasses suggest that they have a similar interaction with respect to DNA binding and transcription. (Ronson et al. 1987; Charles et al. 1992).

The second ORF, ColS, is the sensor kinase member of the two-component system. These sensor kinases share a highly conserved C-terminal domain of approximately 240 amino acids (Albright et al. 1989; Stock et al. 1989, 1990; Charles et al. 1992) in which the autophosphorylated histidine residue and a number of other conserved residues are present. As shown in Figure 4A, these conserved regions are also present in ColS. Most sensor kinases are transmembrane proteins and share two hydrophobic regions in the amino terminus of the protein (Albright et al. 1989; Stock et al. 1989, 1990; Charles et al. 1992). ColS shares this specific feature with known sensor kinases (Fig. 4D). Therefore, it is likely that the amino terminal part of ColS contains a transmembrane spanning domain and is able to detect a change in the environment and that the cytoplasmic carboxy-terminus, containing the conserved histidine residue, is autophosphorylated and is responsible for the interaction with the response regulator.

BasS/BasR and BaeS are two-component systems with an unknown function isolated from $E$. coli (Nagasawa et al. 1993), the PmrA/PmrB two-component system confers resistance to cationic, hydrophobic agents and is suspected to play a role in virulence in S. typhimurium LT2 (Roland et al. 1993), and CpxA confers resistance to the drug amikacin in E. coli (Rainwater and Silverman 1990). The PfeR/PfeS twocomponent system is involved in the regulation of expression of the ferric enterobactin receptor and is induced by enterobactin (Dean and Poole 1993), the response regulator TctD is involved in transport of tricarboxylates (Widenhorn et al. 1989), CopR induces resistance to copper in P. syringae (Mills et al. 1993), and CutR is involved in copper metabolism in $S$. lividans 66 (Tseng and Chen 1991). The $\mathrm{RcaC}$ response regulator is involved in the control of expression of phycobiliproteins as a response in changes of light quality in cyanobacte- 
ria. (Chiang et al. 1992). To us, striking similarities found with a number of response regulators and sensor kinases do not provide a clue for the role of the ColR/ColS two-component system in colonization.

Southern hybridization of chromosomal DNA of other Pseudomonas strains (see Results) showed no homologies when the colR and cols genes were used separately as a probe. This can either be due to the uniqueness of the two-component system or it may be caused by the low level of sequence homology shared among these genes, since only a few boxes in the regulator and sensor are highly conserved (see Figures 3C and 4C). The latter is also observed for LuxI and LuxR homologues, where identification of homologues genes is hampered by the low level of sequence homology that is shared (Salmond et al. 1995).

From these results we conclude that root colonization by $P$. fluorescens WCS365 is an active process in which a so far not identified environmental stimulus, through a two-component system, activates a so far unknown colonization trait. In future research we will attempt to identify the stimulus and the colonization trait.

\section{MATERIAL AND METHODS}

\section{Bacterial strains, plasmids, and growth conditions.}

All strains and plasmids used and their characteristics are listed in Table 3. Cells of the wild-type $P$. fluorescens strain WCS365 and of its Tn5lacZ derivatives were grown overnight at $28^{\circ} \mathrm{C}$ on solidified King B medium (King et al. 1954) or in liquid King B medium under vigorous shaking. The final concentrations of antibiotics in the medium were as follows: nalidixic acid, $15 \mu \mathrm{g} / \mathrm{ml}$; kanamycin, $50 \mu \mathrm{g} / \mathrm{ml}$; and tetracycline, $40 \mu \mathrm{g} / \mathrm{ml}$. Various E. coli strains, which were used for plasmid propagation and for transferring the plasmids to Pseudomonas, were grown overnight in liquid or solidified Luria broth (LB, Sambrook et al. 1989). The antibiotics used for the maintenance of the different plasmids were as described above with the exception of carbenicillin, which was present in a final concentration of $100 \mu \mathrm{g} / \mathrm{ml}$. As an indicator for $\beta$-galactosidase activity, 5-bromo-4-chloro-3-indolyl- $\beta$ D-galactoside (X-gal) was used in a final concentration of $40 \mu \mathrm{g} / \mathrm{ml}$.

\section{DNA modifications.}

For the transfer of plasmids from E. coli to Pseudomonas, triparental mating was performed with pRK2013 as the helper plasmid (Ditta et al. 1980). Acceptor, donor, and helper bacteria from cultures grown overnight on plates were mixed on a King B plate and incubated at $28^{\circ} \mathrm{C}$ overnight. A sample of the mixture was suspended in sterile phosphate-buffered saline solution (PBS; $0.9 \% \mathrm{NaCl}$ buffered with $10 \mathrm{mM}$ sodium phosphate, $\mathrm{pH}$ 7.2) and different dilutions were plated on King $\mathrm{B}$ medium supplemented with the appropriate antibiotics.

Transposon mutagenesis was performed by mating $P$. fluorescens WCS365 with E. coli S17-1 (Simon et al. 1983), a strain harboring the suicide plasmid pCIB100 (Lam et al. 1990) containing a Tn5 with a constitutively expressed lac $Z$ gene. Transconjugants were selected on King B plates supplemented with nalidixic acid $(15 \mu \mathrm{g} / \mathrm{ml})$, kanamycin (50 $\mu \mathrm{g} / \mathrm{ml}$ ), and X-gal. Individual mutants were screened by coinoculation of potato stem cuttings with a 1:1 mixture of cells of the parental strain and the mutant (Simons et al. 1996).
All general DNA techniques, including restriction enzyme digestions, ligations, plasmid isolations, transformation of $E$. coli, and Southern blotting, were performed as described by Sambrook et al. (1989). Both restriction enzymes and T4 ligase were obtained from Pharmacia Biotech LKB, Woerden, The Netherlands.

For the isolation of the fragment located next to the Tn5lacZ insertion, and of the total wild-type gene, the method described by Schnider et al. (1995) and Voisard et al. (1994) was followed. Total chromosomal DNA of mutant PCL1210 was digested with SalI, which preserves the kanamycin resistance gene present on the Tn5lacZ. After digestion of the total chromosomal DNA, all fragments were ligated into pIC20H (Marsh et al. 1984) and a selection was made for kanamycinresistant colonies. After plasmid isolation, the region that is situated next to the Tn5lacZ insertion can be isolated. An EcoRI-EcoRI fragment (see Figures 1 and 2) was isolated from the larger SalI-SalI digest (pMP5203) and this fragment was cloned into pME3049, resulting in plasmid pMP5204. By triparental mating this suicide plasmid was introduced into $P$. fluorescens WCS365 and a selection was made for a single homologous recombination. Digestion of the total chromosomal DNA with BamHI resulted in plasmid pMP5210, which contains the gene fragment of interest (see Figure 2). Complementation was carried out by subcloning the $3.1-\mathrm{kb}$ fragment of pMP5210 (see Figure 1) into the stable plasmid pWTT2081 (van der Bij et al. 1996), resulting in plasmid pMP5242.

For single-stranded DNA sequencing, different fragments of pMP5210 (see Figure 1) were cloned into M13 vector $\operatorname{tg} 130 / 131$ or M13 mp18/19 (Kieny et al. 1983). Singlestranded DNA sequencing was performed according to Sanger et al. (1977) with $\left(\alpha-{ }^{35}\right.$ S)dATP (Amersham International, Little Chalfont, England). T7 and the deaza sequencing kit (Pharmacia) were used according to the manufacturer's guidelines. Primers used for sequencing were obtained from Isogen Bioscience, Maarssen, The Netherlands.

IHF binding studies were performed according to Goosen et al. (1996). For primer extension experiments, mRNA was isolated from an overnight culture of $P$. fluorescens WCS365 according to van Slogteren et al. (1983). To label the primer with $\left(\alpha-{ }^{32} \mathrm{P}\right) \mathrm{dATP}$ (Amersham), polynucleotide kinase (Promega Corporation BNL, Leiden, The Netherlands) was used. Primer extension was performed with approximately $10 \mu \mathrm{g}$ of mRNA with moloney murine leukemia virus reverse transcriptase (M-MLV reverse transcriptase) (Promega) at a temperature of $51^{\circ} \mathrm{C}$.

\section{Generation of a new colonization mutant with homologous recombination.}

Plasmid pMP5268, which contains a tetracycline resistance cassette inserted in the colR gene (see Figure 1), was digested with $N c o I$ and $B g l I I$. Both sticky ends were filled in with the Klenow fragment and the blunt ends were subsequently religated, resulting in plasmid pMP5270. Plasmid pMP5270 was digested with $S p h \mathrm{I}$ and EcoRI, the EcoRI sticky end was filled in with the Klenow fragment and the blunt ends were religated, resulting in plasmid pMP5273. This plasmid contains a part of the cols gene and a part of the colR gene in which a tetracycline resistance gene is inserted. With electroporation, plasmid pMP5273 was introduced into the wild-type $P$. fluo- 
Table 3. Bacterial strains and plasmids used in this study

\begin{tabular}{|c|c|c|}
\hline Bacterial strains and plasmids & Characteristics $^{\mathrm{z}}$ & Reference/source \\
\hline \multicolumn{3}{|l|}{ Pseudomonas spp. } \\
\hline WCS134 & Wild-type strain used for hybridization & Geels and Schippers 1983a; de Weger et al. 1986 \\
\hline WCS379 & Wild-type strain used for hybridization & Geels and Schippers 1983a; de Weger et al. 1986 \\
\hline \multicolumn{3}{|l|}{ P. putida } \\
\hline $\mathrm{RC} 1$ & Wild-type strain used for hybridization & Bolton et al. 1989 \\
\hline WCS085 & Wild-type strain used for hybridization & de Weger et al. 1986 \\
\hline WCS315 & Wild-type strain used for hybridization & de Weger et al. 1986 \\
\hline WCS358 & Wild-type strain used for hybridization & Geels and Schippers $1983 \mathrm{~b}$ \\
\hline \multicolumn{3}{|l|}{ P. fluorescens } \\
\hline WCS365 & $\begin{array}{l}\text { Biocontrol strain in a Fusarium oxysporum } \mathrm{f} \text {. sp. radicis- } \\
\text { lycopersici-tomato system (B. Kroon, personal communica- } \\
\text { tion). Efficient colonizer of the potato root. }\end{array}$ & Geels and Schippers 1983a \\
\hline WCS307 & Wild-type strain used for hybridization & Geels and Schippers $1983 \mathrm{~b}$ \\
\hline WCS374 & Wild-type strain used for hybridization & Geels and Schippers $1983 \mathrm{~b}$ \\
\hline PCL1500 & $\begin{array}{l}\text { Tn5lacZ (Lam et al. 1990) derivative of } P \text {. fluorescens WCS365 } \\
\text { that behaves as its wild type in a gnotobiotic assay. } \mathrm{Nal}^{\mathrm{r}}, \mathrm{Km}^{\mathrm{r}}\end{array}$ & van der Bij et al. 1996 \\
\hline PCL1210 & $\begin{array}{l}\text { Tn5lacZ derivative of } P \text {. fluorescens WCS365 that is impaired in } \\
\text { colonization. } \mathrm{Nal}^{\mathrm{r}}, \mathrm{Km}^{\mathrm{r}}\end{array}$ & Lugtenberg and de Weger 1992 \\
\hline PCL1240 & P. fluorescens WCS365 harboring plasmid pWTT2081. Tc ${ }^{\mathrm{r}}$ & This paper \\
\hline PCL1242 & Mutant PCL1210 complemented with plasmid pMP5242. Tc ${ }^{\mathrm{r}}$ & This paper \\
\hline PCL1251 & $\begin{array}{l}\text { Newly generated mutant with an insertion in the colR and cols } \\
\text { genes (see Materials and Methods). } \mathrm{Tc}^{\mathrm{r}}\end{array}$ & This paper \\
\hline \multicolumn{3}{|l|}{ E. coli } \\
\hline HB101 & $\begin{array}{l}\text { supE44 hsdS20 }\left(r_{B^{-}} m_{B^{-}}\right) \text {recA13 ara-14 proA2 lacY1 galK2 } \\
\text { rpsL20 xyl-5 mtl }-1 \text {. Used for transformation and propagation } \\
\text { of plasmids. }\end{array}$ & Woodcock et al. 1989 \\
\hline XL1-Blue & 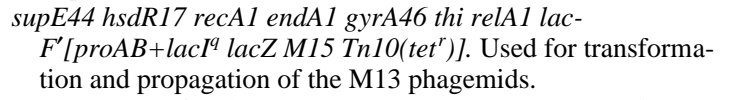 & Stratagene, La Jolla, CA \\
\hline $\mathrm{DH} 5 \alpha$ & $\begin{array}{l}\text { endA1 gyrSA96 hrdR17( } r K-m K-) \text { supE44 recAl. Used for trans- } \\
\text { formation and propagation of plasmids. }\end{array}$ & Boyer and Roulland-Dussoix 1969 \\
\hline S17-1 & MM294, RP4-2:Mu-Km::Tn 7 chromosomally integrated & Simon et al. 1983 \\
\hline \multicolumn{3}{|l|}{ Plasmids } \\
\hline pRK2013 & Helper plasmid for triparental mating & Ditta et al. 1980 \\
\hline pME3049 & Suicide plasmid used for picking up wild-type genes, $\mathrm{Km}^{\mathrm{r}}$ & Voisard et al. 1994 \\
\hline pIC20H & $\mathrm{Cb}^{\mathrm{r}}$ & Marsh et al. 1984 \\
\hline pWTT2081 & $\begin{array}{l}\text { Plasmid stable in the rhizosphere and used for complementation } \\
\text { of the mutants, copy number } 4 \text { to } 9 \text { copies } / \text { cell. Tc }{ }^{r}\end{array}$ & van der Bij et al. 1996 \\
\hline pMP5203 & $\begin{array}{l}\text { pIC20H that contains a SalI-SalI fragment of the chromosomal } \\
\text { region of PCL1210 flanked by a Tn 5lacZ fragment containing } \\
\mathrm{Km}^{\mathrm{r}} \cdot \mathrm{Cb}^{\mathrm{r}}, \mathrm{Km}^{\mathrm{r}}\end{array}$ & This paper \\
\hline pMP5204 & $\begin{array}{l}\text { pME3049 that contains a } 1.5-\mathrm{kb} \text { EcoRI-EcoRI fragment of } \\
\text { pMP5203 (see Figure 2) used for homologous recombination } \\
\text { with } P \text {. fluorescens WCS365. } \mathrm{Km}^{\mathrm{r}}\end{array}$ & This paper \\
\hline pMP5210 & $\begin{array}{l}\text { pME3049 containing a 3.1-kb fragment of } P \text {. fluorescens } \\
\text { WCS365 obtained by homologous recombination and spa n- } \\
\text { ning the Tn } 5 \text { lacZ insertion. } \mathrm{Km}^{\mathrm{r}}\end{array}$ & This paper \\
\hline pMP5216/17 & $\begin{array}{l}\text { M13tg130 (Kieny et al. 1983) containing a 2.5-kb EcoRI-EcoRI } \\
\text { fragment in two orientations of pMP5210 (see Figure 2) used } \\
\text { for single-strand sequencing. }\end{array}$ & This paper \\
\hline pMP5218/19 & $\begin{array}{l}\text { M13mp18/19 containing a 2-kb SalI-BamHI fragment of } \\
\text { pMP5203 (see Figure 2) used for single-strand-sequencing }\end{array}$ & This paper \\
\hline pMP5220/21 & $\begin{array}{l}\text { M13mp18/19 containing a 0.8-kb BamHI-SmaI fragment of } \\
\text { pMP5110 (see Figure 2) used for single-strand sequencing }\end{array}$ & This paper \\
\hline pMP5242 & $\begin{array}{l}\text { pWTT2081 containing the total 3.1-kb complementing fragment } \\
\text { of pMP5210 that is used to complement mutant PCL1210. Tc }{ }^{r}\end{array}$ & This paper \\
\hline pMP5268 & $\begin{array}{l}\text { 3.1-kb complementing kb fragment of pMP5210 cloned into } \\
\text { pIC20H and digested with SmaI. Subsequently, a Tc cassette } \\
\text { obtained from pWTT2081 is inserted in this SmaI site (see } \\
\text { Figure 1). }\end{array}$ & This paper \\
\hline pMP5270 & $\begin{array}{l}\text { pMP5268 digested with } N c o \text { I and } B g l \mathrm{II} \text {; the sticky ends are } \\
\text { filled in and the plasmid is rel igated (see Figure 1). }\end{array}$ & This paper \\
\hline pMP5273 & $\begin{array}{l}\text { pMP5270 digested with } S p h \mathrm{I} \text { and EcoRI; the sticky end is filled } \\
\text { in and the plasmid is religated.(see Figure 1). }\end{array}$ & This paper \\
\hline
\end{tabular}

${ }^{\mathrm{z}}$ Abbreviations: Nal, nalidixic acid; $\mathrm{Cb}$, carbenicillin; Km, kanamycin; Tc, tetracycline. 
rescens WCS365. This plasmid behaves as a suicide plasmid in P. fluorescens WCS365 and a selection was made for homologous recombination (single or double) by selection for tetracycline resistance. The newly generated mutant, PCL1251, was subsequently checked by Southern hybridization for the presence of plasmid pMP5273 in the genome (results not shown) and tested for its competitive colonization abilities (see Table 2).

\section{Growth of mutant PCL1210 cells in competition with parental cells.}

Overnight cultures of the mutant and the wild type in liquid SSM (Meyer and Abdallah 1978) were washed in sterile PBS and subsequently diluted in SSM to a final optical density value at $620 \mathrm{~nm}$ of 0.1 . Equal volumes of these cultures were mixed. The mixture was allowed to grow for $24 \mathrm{~h}$ diluted 1,000 -fold. This procedure was conducted five times. The ratio between the wild-type and the mutant cells was determined at various time intervals by plating diluted samples on solidified King B medium containing X-gal. White and blue colonies represent wild-type and mutant cells, respectively.

\section{Colonization experiments on plants.}

Overnight cultures in King B medium were washed once in sterile PBS and the bacteria of the individual strains were diluted in sterile PBS to a final concentration of $10^{7} \mathrm{CFU} / \mathrm{ml}$. These suspensions were mixed 1:1 ( $\mathrm{vol} / \mathrm{vol})$ and the mixture was used to inoculate sterile potato stem cuttings or germinated seeds of tomato, radish, or wheat. The colonization experiments were designed to test the ability of a strain to move with or toward the growing root tip. When sterile potato stem cuttings were worked with, the procedure of de Weger et al. (1994) for colonization was used with the following modifications. Three milliliters of sterile PNS (plant nutrient solution), containing $5 \mathrm{mM} \mathrm{Ca}\left(\mathrm{NO}_{3}\right)_{2}, 5 \mathrm{mM} \mathrm{KNO} \mathrm{KN}_{3}, 2 \mathrm{mM}$ $\mathrm{MgSO}_{4}, 1 \mathrm{mM} \mathrm{KH}{ }_{2} \mathrm{PO}_{4}$, and micronutrients (Hoffland et al. 1989) was added to a quartz sand column that was applied into the glass tube in a dry form. This results in a compact, moisturized sand column. After sterilization, $2 \mathrm{ml}$ of water agar (sterile water containing $1 \%$ agar) was put on top of the compact sand column to prevent desiccation and to enable us to plant the fragile inoculated stem cuttings into the agar layer.

When germinated seeds were used for colonization experiments, the sand column used was slightly different. We refer to this system as the standard sand column. The glass tube of this recently described gnotobiotic system (Simons et al. 1996) was filled with sterile sand that had been mixed with sterile PNS (10\% PNS) prior to deposition in the glass tube. The inoculated seedling was subsequently planted on top of the aerated sand column (Simons et al. 1996).

After 14 days of growth in the gnotobiotic compact system described by de Weger et al. (1994) or 7 days of growth in the standard system described by Simons et al. (1996), the plants were removed from the sand tube and the bacteria that had been able to reach the root were isolated as follows. The root tips $(1$ to $2 \mathrm{~cm})$ were removed and shaken vigorously in the presence of adhering sand particles in $1.0 \mathrm{ml}$ of PBS on an Eppendorf shaker for 15 min to remove the bacteria. The bacterial suspensions thus obtained were plated on King B plates containing X-gal, with a spiral plater (Spiral Systems, Cincinnati, $\mathrm{OH})$. After incubation at $28^{\circ} \mathrm{C}$ for 2 days, the colonies were distinguished by their yellow/white (wild type) and blue (mutant) appearance on plate. The number of CFU per $\mathrm{cm}$ of root tip were calculated (Davies and Whitbread 1989), and the data transformed to $\log _{10}(\mathrm{CFU} / \mathrm{cm}+1)$ values (Loper and Schroth 1984), after which estimates of the mean and standard deviation were calculated. Experiments were performed in 10fold, and conducted twice. Statistical comparison of strains in mixed inocula was done with the nonparametric WilcoxonMann-Whitney test (Sokal and Rohlf 1981). For analysis of mutant behavior from mixed inocula, only plates with more than 30 colonies per plate $\left(5 \times 10^{3} \mathrm{CFU} / \mathrm{cm}\right)$ were counted. Zeroes were included for analysis of single inocula (Kloepper and Beauchamp 1992). Calculation of $\log _{10}(\mathrm{CFU} / \mathrm{cm}+1)$ was chosen to avoid non-existent $\log _{10}(0)$ situations.

To determine the number of mutant and parental bacteria on the upper parts of the root system, the isolated roots were divided into three parts of equal length and the number and ratio of mutant and wild type present on these root segments were determined.

\section{Growth on various carbon sources.}

The Biolog system (Bochner 1989) (Biolog, Hayward, CA) was used according to the manufacturer's guidelines to determine differences in the ability of mutant and wild type to oxidize 95 different $\mathrm{C}$-sources, some of which may be present in exudate and therefore may play a role in colonization.

To determine whether the two-component system is involved in the uptake of various $\mathrm{C}$-sources present in root exudate, we compared the growth curves of the wild type and the mutant in minimal media supplemented with the following $\mathrm{C}$ sources: malic acid, fumaric acid, succinic acid, citric acid, glucose, ribose, fructose, maltose, and galactose. The Csources used for this experiment are present in the tomato seed exudate (M. Simons, unpublished; Lugtenberg et al. 1996).

For the measurement of growth rate at high substrate concentrations, wild-type and mutant cells of an overnight culture grown in BM (basic medium; i.e., SSM without succinic acid, M. Simons, unpublished) supplemented with $0.2 \%$ succinic acid, were washed, and diluted to approximately $10^{7} \mathrm{CFU} / \mathrm{ml}$ in BM in which succinic acid was replaced by $0.2 \%$ of various other C-sources described to be present in tomato root exudate. The cells were incubated at $28^{\circ} \mathrm{C}$ on a rotary shaker and the $\mathrm{OD}_{620}$ values of these suspensions were measured every 60 min for $9 \mathrm{~h}$.

Growth at low substrate concentrations was performed in BM supplemented with tomato root exudate as the carbon source. Tomato root exudate was obtained by incubating approximately 7 sterile germinating tomato seeds for 8 days in 5 $\mathrm{ml}$ of sterile PNS. The root exudate samples thus isolated were tested for sterility and the sterile samples were pooled. BM supplemented with tomato root exudate was inoculated with $10^{2}$ to $10^{3} \mathrm{CFU} / \mathrm{ml}$ of a $1: 1$ mixture of the washed cells of the wild type and the mutant. Increases in bacterial populations were measured every $24 \mathrm{~h}$ by dilution plating of samples on solidified King B medium supplemented with X-gal.

\section{Motility, chemotaxis, and isolation of LPS and cell envelopes.}

Motility was measured with semisolid $(0.35 \%$ agar $)$ plates containing 20-fold diluted King B. Chemotaxis toward various 
carbon sources was measured with semisolid plates $(0.35 \%$ agar) containing BM medium supplemented with various carbon sources, as described above, and X-gal (Armstrong et al. 1967).

Isolation of cell envelopes and analysis of LPS ladder patterns and membrane protein patterns were performed according to de Weger et al. (1987a).

\section{ACKNOWLEDGMENTS}

We thank D. Haas for the supply of the pME3049 plasmid and N. Goossen, Gorlaeus Laboratories, Leiden University, Leiden, The Netherlands, for supply of the purified IHF protein and technical assistance. Furthermore, we thank Thomas Chin-A-Woeng for electron microscopy data and Ineke Brand for the isolation of mutant PCL1210. The investigations were partly funded by the European Union Biotech program BIO2-CT93.0196.

\section{LITERATURE CITED}

Albright, L. M., Huala, E., and Ausubel, F. M. 1989. Prokaryotic signal transduction mediated by sensor and regulator protein pairs. Annu. Rev. Genet. 23:311-336.

Armstrong, J. B., Adler, J., and Dahl, M. M. 1967. Nonchemotactic mutants of Escherichia coli. J. Bacteriol. 93:390-398.

Bochner, B. R. 1989. Sleuthing out bacterial identities. Nature 339:157158.

Bolton, H., Jr., Elliott, L. F., Gurusidaiah, S., and Fredrickson, J. K. 1989. Characterization of a toxin produced by a rhizobacterial Pseudomonas sp. that inhibits wheat growth. Plant Soil 114:279-287.

Boyer, H. W., and Roulland-Dussoix, D. 1969. A complementation analysis of the restriction and modification of DNA in Escherichia coli. J. Mol. Biol. 41:459-472.

Brand, J., Lugtenberg, B. J. J., Glandorf, D. C. M,. Bakker, P. A. H. M., Schippers, B., and de Weger, L. A. 1990. Isolation and characterization of a superior potato root-colonizing Pseudomonas strain. Pages 350-354 in: Plant growth-promoting rhizobacteria-progress and prospects. IOBC/WPRS Bull. XIV-8. C. Keel, B. Koller, and G. Défago, eds. Interlaken, Switzerland.

Charles, T. C., Jin, S., and Nester, E. W. 1992. Two-component sensory systems in phytobacteria. Annu. Rev. Phytopathol. 30:463-484.

Chiang, G. G., Schaeffer, M. R., and Grossman, A. R. 1992. Complementation of a red-light-indifferent cyanobacterial mutant. Proc. Natl. Acad. Sci. USA 89:9415-9419.

Comeau, D. E., Ikenaka, K., Tsung, K., and Inouye, M. 1985. Primary characterization of the protein products of the Escherichia coli ompB locus: Structure and regulation of synthesis of the OmpR and EnvZ proteins. J. Bacteriol. 164:578-584.

Davies, K. G., and Whitbread, R. 1989. A comparison of methods for measuring the colonization of a root system by fluorescent Pseudomonads. Plant Soil 116:39-246.

de Weger, L. A., Bakker, P. A. H. M., Schippers, B., van Loosdrecht, M. C. M., and Lugtenberg, B. J. J. 1989. Pseudomonas spp. with mutational changes in the O-antigenic side chain of their lipopolysaccharide are affected in their ability to colonize potato roots. Pages 197202 in: Signal molecules in plants and plant-microbe interactions, NATO ASI Series vol. H36. B. J. J. Lugtenberg, ed. Springer-Verlag Berlin.

de Weger, L. A., Dekkers, L. C., van der Bij, A. J., and Lugtenberg, B. J. J. 1994. Use of phosphate-reporter bacteria to study phosphate limitation in the rhizosphere and in bulk soil. Mol. Plant-Microbe Interact. 7:32-38.

de Weger, L. A., Jann, B., Jann, K., and Lugtenberg, B. J. J. 1987a. Lipopolysaccharides of Pseudomonas spp. that stimulate plant growth: Composition and use for strain identification. J. Bacteriol. 169:1441-1446.

de Weger, L. A., van Boxtel, R., van der Burg, B., Gruters, R., Geels, F. P., Schippers, B., and Lugtenberg, B. 1986. Siderophores and outer membrane proteins of antagonistic plant-growth-stimulating, rootcolonizing Pseudomonas spp. J. Bacteriol. 165:585-594.

de Weger, L. A., van der Vlugt, C. I. M., Wijfjes, A. H. M., Bakker, P. A.
H. M., Schippers, B., and Lugtenberg, B. J. J. 1987b. Flagella of a plant-growth-stimulating Pseudomonas fluorescens strain are required for colonization of potato roots. J. Bacteriol. 169:2769-2773.

Dean, C. R., and Poole, K. 1993. Expression of the ferric enterobactin receptor (PfeA) of Pseudomonas aeruginosa: Involvement of a two-component regulatory system. Mol. Microbiol. 8:1095-1103.

Ditta, G., Stanfield, S., Corbin, D., and Helinski, D. R. 1980. Broad host range DNA cloning system for Gram-negative bacteria: Construction of a gene bank of Rhizobium meliloti. Proc. Natl. Acad. Sci. USA 77: 7347-7351.

Geels, F. P., and Schippers, B. 1983a. Selection of antagonistic fluorescent Pseudomonas spp. and their root colonization and persistence following treatment of seed potatoes. Phytopathol. Z. 108:193-206.

Geels, F. P., and Schippers, B. 1983b. Reduction of yield depressions in high frequency potato cropping soil after seed tuber treatments with antagonistic fluorescent Pseudomonas spp. Phytopathol. Z. 108:207221.

Glandorf, D. C. M. 1992. Root colonization by fluorescent pseudomonads. Ph.D. thesis. University of Utrecht, Utrecht, The Netherlands.

Goosen, N., and van de Putte, P. 1995. The regulation of transcription initiation by integration host factor. Mol. Microbiol. 16:1-7.

Goosen, N., van Ulsen, P., Zulianello, L., and van de Putte, P. 1996. Transcription activation by histon-like protein integration host factor. Methods Enzymol. 274:232-242

Hoffland, E., Findenegg, G. R., and Nielemans, J. A. 1989. Solubilization of rock phosphate by rape. Plant Soil 113:161-165.

Kieny, M. P., Lathe, R., and Lecocq, J. P. 1983. New versatile cloning and sequencing vectors based on bacteriophage M13. Gene 26:91-99.

King, E. O., Ward, M. K., and Raney, D. E. 1954. Two simple media for the demonstration of pyocyanin and fluorescin. J. Lab. Clin. Med. 44: 301-307.

Kloepper, J. W., and Beauchamp, C. J. 1992. A review of issues related to measuring colonization of plant roots by bacteria. Can. J. Microbiol. 38:1219-1232.

Kyte, J., and Doolittle, R. F. 1982. A simple method for displaying the hydropathic character of a protein. J. Mol. Biol. 157:105-132.

Lam, S. T., Ellis, D. M., and Ligon, J. M. 1990. Genetic approaches for studying rhizosphere colonization. Plant Soil 129:11-18.

Loper, J. E., and Schroth, M. N. 1984. Lognormal distribution of bacterial populations in the rhizosphere. Phytopathology 74:1454-1460.

Lugtenberg, B., van der Bij, A. J., Bloemberg, G., Chin A Woeng, T., Dekkers, L., Kravchenko, L., Mulders, I., Phoelich, C., Simons, M., Spaink, H., Tikhonovich, I., de Weger, L., and Wijffelman, C. 1996. Molecular basis of rhizosphere colonization by Pseudomonas bacteria. Pages 433-440 in: Biology of Plant-Microbe Interactions. G. Stacey, B. Mullin, and P. M. Gresshoff, eds. International Society for Molecular Plant-Microbe Interactions, St. Paul, MN.

Lugtenberg, B. J. J., and de Weger, L. A. 1992 Plant root colonization by Pseudomonas spp.. Pages 13-19 in Pseudomonas: Molecular Biology and Biotechnology. E. Galli, S. Silver, and B. Witholt, eds. American Society for Microbiology, Washington, DC.

Lugtenberg, B. J. J., de Weger, L. A., and Bennett, J. W. 1991. Microbial stimulation of plant growth and protection from disease. Curr. Opin. Biotechnol. 2:457-464.

Lugtenberg, B. J. J, de Weger, L. A, and Schippers, B. 1994. Bacterization to protect seed and rhizosphere against disease. Pages 293-302 in: Seed treatment: Progress and prospects. BCPC monograph no. 57.

Makino, K., Shinagawa, H., Amemura, M., and Nakata, A. 1986. Nucleotide sequence of the $p h o B$ gene, the positive regulatory gene for the phosphate regulon of Escherichia coli. J. Mol. Biol. 190:37-44.

Marsh, J. L., Erfle, M., and Wykes, E. J. 1984. The pIC plasmid and phage vectors with versatile cloning sites for recombinant selection by insertional inactivation. Gene 32:481-485.

Meyer, J. M., and Abdallah, M. A. 1978. The fluorescent pigment of Pseudomonas fluorescens: Biosynthesis, purification and physicochemical properties. J. Gen. Microbiol. 107:319-328.

Miller, V. L., Taylor, R. K., and Mekalanos, J. J. 1987. Cholera toxin transcriptional activator ToxR is a transmembrane DNA binding protein. Cell 48:271-279.

Mills, S. D., Jasalavitch, C. A., and Cooksey, D. A. 1993. A two-component regulatory system required for copper-inducible expression of the copper resistance operon of Pseudomonas syringae. J. Bacteriol. 175: $1656-1664$. 
Nagasawa, S., Ishige, K., and Mizuno, T. 1993. Novel members of the two-component signal transduction genes in Escherichia coli. J. Biochem. 114:350-357.

Plunkett, G., Burland, V., Daniels, D. L., and Blattner, F. R. 1993. Analysis of the Escherichia coli genome. III. DNA sequence of the region from 87.2 to 89.2 minutes. Nucleic Acids Res. 21:3391-3398.

Rainwater, S., and Silverman, P. M. 1990. The Cpx proteins of Escherichia coli $\mathrm{K}-12$ : Evidence that $\operatorname{cpxA}$, ecfB, ssd, and eup mutations all identify the same gene. J. Bacteriol. 172:2456-2461.

Roland, K. L., Martin, L. E., Esther, C. R., and Spitznagel, J. K. 1993. Spontaneous pmrA mutants of Salmonella typhimurium LT2 define a new two-component regulatory system with a possible role in virulence. J. Bacteriol. 175:4154-4164.

Ronson, C. W., Nixon, B. C., and Ausubel, F. M. 1987. Conserved domains in bacterial regulatory proteins that respond to environmental stimuli. Cell 49:579-581.

Salmond, G. P. C., Bycroft, B. W., Stewart, G. S. A. B., and Williams, P. 1995. The bacterial 'enigma': Cracking the code of cell-cell communication. Mol. Microbiol. 16:615-624.

Sambrook, J., Fritsch, E. F., and Maniatis, T. A. 1989. Molecular Cloning: A Laboratory Manual. 2nd ed. Cold Spring Harbor Laboratory, Cold Spring Harbor, NY.

Sanger, F., Nicklen, S., and Coulson, A. R. 1977. DNA sequencing with chain-termination inhibitors. Proc. Natl. Acad. Sci. USA 74: 5463-5467.

Schippers, B., Bakker, A. W., and Bakker, P. A. H. M. 1987. Interactions of deleterious and beneficial rhizosphere microorganisms and the effect of cropping practices. Annu. Rev. Phytopathol. 25:339-358.

Schnider, U., Keel, C., Voisard, C., Défago, G., and Haas, D. 1995. Tn5directed cloning of pqq genes from Pseudomonas fluorescens $\mathrm{CHAO}$ : Mutational inactivation of the genes results in overproduction of the antibiotic pyoluteorin. Appl. Environ. Microbiol. 61:3856-3864.

Schroth, M. N., and Hancock, J. G. 1982. Disease-suppressive soil and root-colonizing bacteria. Science 216:1376-1381.

Simon, R., Priefer, U., and Pühler, A. 1983. A broad host range mobilization system for in vivo genetic engineering: Transposon mutagenesis in gram negative bacteria. Bio/Technology 1:784-791.

Simons, M., Permentier, H. P., de Weger, L. A., Wijffelman, C. A., and Lugtenberg, B. J. J. 1997. Amino acid synthesis is necessary for tomato root colonization by Pseudomonas fluorescens strain WCS365. Mol. Plant-Microbe Interact. 10:102-106.

Simons, M., van der Bij, A. J., Brand, I., de Weger, L. A., Wijffelman, C. A., and Lugtenberg, B. J. J. 1996. Gnotobiotic system for studying rhizosphere colonization by plant growth-promoting Pseudomonas bacteria. Mol. Plant-Microbe Interact. 9:600-607.
Sokal, R. R., and Rohlf, F. J. 1981. Biometry. Freeman, San Francisco. Stock, J. B., Ninfa, A. J., and Stock, A. M. 1989. Protein phosphorylation and regulation of adaptive responses in bacteria. Microbiol. Rev. 53:450-490.

Stock, J. B., Stock, A. M., and Mottonen, J. M. 1990. Signal transduction in bacteria. Nature 344:395-400.

Stock, J. B., Surette, M. G., Levit, M., and Park, P. 1995. Twocomponent signal transduction systems: Structure function relationships and mechanisms of catalysis. Pages 25-51 in: Two-Component Signal Transduction. J. A. Hoch and T. J. Silhavy, eds. ASM Press, Washington, DC.

Swanson, R. V., Alex, L. A., and Simon, M. I. 1994. Histidine and aspartate phosphorylation: Two-component systems and the limits of homology. TIBS 19:485-490.

Thomashow, L. S., and Weller, D. M. 1996. Current concepts in the use of introduced bacteria for biological disease control: Mechanisms and antifungal metabolites. Pages 236-271 in: Plant-Microbe-Interactions. G. Stacey and N. T. Keen, eds. 1st ed. Vol. 1. Chapman and Hill, New York.

Tseng, H.-C., and Chen, C. W. 1991. A cloned ompR-like gene of Streptomyces lividans 66 suppresses defective melC1, a putative copper-transfer gene. Mol. Microbiol. 5:1187-1196.

van der Bij, A. J., de Weger, L. A., Tucker, W. T., and Lugtenberg, B. J. J. 1996. Plasmid stability in Pseudomonas fluorescens in the rhizosphere. Appl. Environ. Microbiol. 62:1076-1080.

van Slogteren, G. M. S., Hoge, J. H. C., and Hooykaas, P. J. J. 1983. Clonal analysis of heterogeneous crown gall tumour tissues induced by wild-type and shooter mutant strains of Agrobacterium tumefaciens: Expression of T-DNA genes. Plant Mol. Biol. 2:321-333.

Voisard, C., Bull, C. T., Keel, C., Laville, J., Maurhofer, M., Schnider, U., Défago, G., and Haas, D. 1994. Biocontrol of root diseases by Pseudomonas fluorescens CHA0: Current concepts and experimental approaches. Pages 67-89 in: Molecular Ecology of Rhizosphere Microorganisms. F. O'Gara, D. N. Dowling, and B. Boesten, eds. VCH Verlagsgesellschaft, Weinheim, Germany.

Weller, D. M. 1988. Biological control of soilborne plant pathogens in the rhizosphere with bacteria. Annu. Rev. Phytopathol. 26:379-407.

Widenhorn, K. A., Somers, J. M., and Kay, W. W. 1989. Genetic regulation of the tricarboxylate transport operon (tctI) of Salmonella typhimurium. J. Bacteriol. 171:4436-4441.

Woodcock, D. M., Crowther, P. J., Doherty, J., Jefferson, S., DeCruz, E., Noyer-Weidner, M., Smith, S. S., Michael, M. A., and Graham, M. W. 1989. Quantitative evaluation of Escherichia coli host strains for tolerance to cytosine methylation in plasmid and phage recombinants. Nucleic Acids Res. 17:3469-3478. 